IRA-International Journal of Management \&

Social Sciences

ISSN 2455-2267; Vol.09, Issue 01 (October 2017)

Pg. no. 8-13

Institute of Research Advances

http://research-advances.org/index.php/RAJMSS

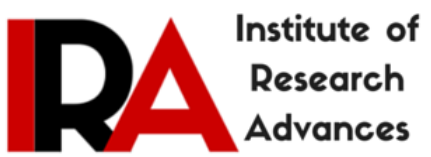

\title{
Convergence of Assets under MGNREGS: Case from Amritsar District of Punjab
}

\author{
Dr. Shankar Chatterjee \\ Former Prof. \& Head (CPME) \\ NIRD \& PR, Hyderabad-500 030, Telangana, India
}

Type of Review: Peer Reviewed.

DOI: http://dx.doi.org/10.21013/jmss.v9.v1.p2

\section{How to cite this paper:}

Chatterjee, S. (2017). Convergence of Assets under MGNREGS: Case from Amritsar District of Punjab. IRA-International Journal of Management \& Social Sciences (ISSN 2455-2267), 9(1), 8-13. doi:http://dx.doi.org/10.21013/jmss.v9.n1.p2

(C) Institute of Research Advances.

\section{(cc) $\mathrm{BY}-\mathrm{NC}$}

This work is licensed under a Creative Commons Attribution-Non Commercial 4.0 International License subject to proper citation to the publication source of the work.

Disclaimer: The scholarly papers as reviewed and published by the Institute of Research Advances (IRA) are the views and opinions of their respective authors and are not the views or opinions of the IRA. The IRA disclaims of any harm or loss caused due to the published content to any party.

Institute of Research Advances is an institutional publisher member of Publishers Inter Linking Association Inc. (PILA-CrossRef), USA. The institute is an institutional signatory to the Budapest Open Access Initiative, Hungary advocating the open access of scientific and scholarly knowledge. The Institute is a registered content provider under Open Access Initiative Protocol for Metadata Harvesting (OAI-PMH).

The journal is indexed \& included in WorldCat Discovery Service (USA), CrossRef Metadata Search (USA), WorldCat (USA), OCLC (USA), Open J-Gate (India), EZB (Germany) Scilit (Switzerland), Airiti (China), Bielefeld Academic Search Engine (BASE) of Bielefeld University, Germany, PKP Index of Simon Fraser University, Canada. 


\begin{abstract}
Mahatma Gandhi National Rural Employment Guarantee Act (MGNREGA) is a historic rural development Act aims to guarantee the 'right to work' through passing an Act in the Parliament. The Act while in implementation is known as Scheme so it is known as Mahatma Gandhi National Rural Employment Guarantee Scheme (MGNREGS). MGNREGA/MGNREGS is a powerful instrument for ensuring inclusive growth in rural India through its impact on social protection, livelihood security and democratic empowerment. In this note, a case where convergence of assets was initiated is presented from Dalam panchayat, Harshe Chinna block of Amritsar district. The study was carried out during first week of August 2017 by visiting the area.
\end{abstract}

Keywords: Amritsar district, MGNREGA/MGNREGS and Park cum play ground.

\begin{abstract}
About MGNREGA/ MGNREGS:
The Mahatma Gandhi National Rural Employment Guarantee Act, 2005 (MGNREGA) was notified on September 7, 2005 with the mandate to provide at least 100 days of guaranteed wage employment in a financial year to every rural household whose adult members volunteer to do unskilled manual work. And for this, job card was issued to each house hold. The Act while in implementation is known as Scheme so it is known as Mahatma Gandhi National Rural Employment Guarantee Scheme (MGNREGS). It is a historic rural development Scheme as it aims to guarantee the 'right to work' through passing an Act in the Parliament.

For the benefit of readers important goals of the Act are presented below:

Goals:

i. Social protection for the most vulnerable people living in rural India by providing employment opportunities

ii. Livelihood security for the poor through creation of durable assets, improved water security, soil conservation and higher land productivity

iii. Drought-proofing and flood management in rural India

iv. Empowerment of the socially disadvantaged, especially women, Scheduled Castes (SCs) and Schedules Tribes (STs), through the processes of a rights-based legislation

v. Strengthening decentralized, participatory planning through convergence of various anti-poverty and livelihoods initiatives

vi. Deepening democracy at the grass-roots by strengthening Panchayati Raj Institutions

vii. Effecting greater transparency and accountability in governance (http://nrega.nic.in/netnrega/guidelines.aspx/11 September 2017).
\end{abstract}

It is pertinent to mention that it is a massive scheme in the world and its progress in one year (2016-17) may be seen from the following table.

Table: 1: Physical progress of MGNREGS during 2016-17

(a) Approved Labour Budget: (In Rs) 2209274000
(b) Person-days Generated so far: 2358312000
(c) $\%$ of Total Labour Budget: 106.75
(d) SC Person-days \% as of total Person-days: 21.27
(e) ST Person-days \% as of total Person-days: 17.61
(f) Women Person-days out of Total (\%): 56.13
(g) Average days of employment provided per household: 46.03
(h) Average Wage rate per day per person (Rs.):161.67
(i) Total No of HHs completed 100 days of wage employment: 3990866
(j) Total Households Worked: 51233000
(k) Total Individuals Worked: 76682000
Source: http://ruraldiksha.nic.in/RuralDashboard/MGNREGA_NEW.aspx/dt10-9-2017
The table is self-explanatory but important points as observed are:
Approved labour budget was Rs 2209274000
Total households worked were 51233000
Total individuals worked were 76682000


The important observations from the data are crores of money were spent as labor budget and crores of households were involved in MGNREGS.

MGNREGA/MGNREGS is a powerful instrument for ensuring inclusive growth in rural India through its impact on social protection, livelihood security and democratic empowerment. For better implementation of the Scheme new guidelines have been issued which have been collected from nrega.nic.in/circular_archive.

Guidelines for the New / Additional Works Permitted Under MGNREGA/MGNREGS:

To strengthen the positive synergy between MGNREGS and agriculture and allied rural livelihoods, to respond to the demands of the States for greater location specific flexibility in permissible works and to help improve the ecological balance in rural India and to provide a cleaner, healthier environment for the rural population, it has been decided to expand the list of permissible works as under.

$>$ All works shall be approved by the Gram Sabha and the Gram Panchayat and shall be part of the Annual Shelf of Projects.

$>$ The unit costs included in the works below are indicative and project costs for each work will be estimated depending on the Schedule of Rates (SoR's) prevalent in the respective region/area of work.

$>$ For works to be taken up on private land and homestead, the individual land owner shall be a job card holder and also work in the project.

$>$ The works that lead to creation of durable assets may be taken up under MGNREGS.

$>$ Items of expenditure that are recurring in nature and/or do not lead to creation of durable assets, are not permitted under MGNREGS.

\section{Issues related to MGNREGS:}

Although MGNREGS is a well planned Scheme for rural households who seek wage employment but there are some issues pertaining to MGNREGS so instead of highlighting many issues, important issue from the news paper The Indian Express, July 10, 2017 under the title of "MGNREGA wages less than minimum farm wages in 15 states: Panel" may be mentioned which speaks many things.

As per the news item "The Committee for revision of wages paid under the Mahatma Gandhi National Rural Employment Guarantee Act (MGNREGA) has found that minimum agricultural wages are higher than MGNREGA wages in 15 states. An upward revision in MGNREGA wages is estimated to require Rs 4,500 crore increase in its budget.

Based on these findings, the panel, under Additional Secretary in the Ministry of Rural Development Nagesh Singh, is expected to make its recommendations in another month.

As per data being examined by the committee, the minimum wages paid to agricultural workers are significantly higher than MGNREGA wages in Karnataka, Punjab, Jharkhand, Uttarakhand, West Bengal, Mizoram, and Andaman and Nicobar Islands.

The other states where MGNREGA wages fail to match up are Sikkim, Andhra Pradesh, Telangana, Haryana, Madhya Pradesh and Bihar. In Rajasthan and Himachal Pradesh, the minimum wages are marginally higher than MGNREGA wages".

\section{Study area and Methodology:}

In this section a case portraying convergence of assets under MGNREGS from Dalam panchayat, Harshe Chinna block of Amritsar district of Punjab is presented. The study was carried out during first week of August 2017 by visiting the area.

\section{Convergence of assets created under MGNREGS from Amritsar District of Punjab:}

Before presenting the case, it is pertinent to mention that Amritsar city is an old city and popular in the world because of Golden Temple (Harmandir Sahib) which is the holiest Gurdwara (religious place) of the Sikh religion. So the author's first visit to Golden Temple has created a different environment as everywhere one can find selfless service whether serving of food, water, cleaning of utensils, making of roti etc are concerned. It is heartening to mention by quoting Hindustan Times, $19^{\text {th }}$ May 2016, epaper, that "The Golden Temple (Harmandir Sahib) in 
Amritsar has been ranked number 3 in the country on the travelers' choice landmarks list of a leading travel planning and booking site TripAdvisor. Surrounded by a holy 'sarovar', its construction was completed in 1604 and presently runs one of the largest free kitchens in the world, which serves an average of 1,00,000 people daily".

The case, where convergence of assets was taken up under MGNREGS/MGNREGA, is from Dalam panchayat, Harshe Chinna block of Amritsar district where the author visited in the first week of August. In Dalam panchayat lands were lying vacant and in order to use the land fruitfully as well as with the objective of prevention for encroaching, an innovative idea by converging of three assets were designed by the gram panchayat. These three were a park cum play aground, a drain adjacent to the park and an approach road connecting the park cum play ground. In this park cum play ground which was the focus among the assets, children can play vis-a-vis old persons can stroll and gossip thus all can pass their time in constructive way.

The project (park cum play ground) was spread over to an area of about one acre. It is having sitting arrangements as eight concrete benches have been constructed so that elderly persons can sit and chit chat. Further, in all the four border-sides with inter locking brick, walking-path was constructed. Inside the park cum play ground, with green grass all the area was covered. In addition, outside the park in order to avoid water storage so that mosquito etc. cannot breed, one drain of 500 meters in length and about two feet in width was constructed. Moreover, one approach road from the main road to the park with brick was also created. The approach road was around 500 meters and its width was about 30 feet with all bricks and thus sustainable asset was created.

All the lands, where the assets in convergence mood were created, belonged to Gram Panchayat so free from litigation. The works were started in the financial year of 2014-15 and completed in 2015-16. Since expenditure on materials was more than the labour cost so the total costs for creating all the three assets viz., park cum play ground, approach road and drain were to the tune of Rs. 7 lakh. Convergence of assets was observed as elderly persons can stroll freely on the brick road, mosquito cannot breed because of the drain and children and elderly people can use the park cum play ground without fearing of pollution For maintaining the park, one local person as Mali (gardener) was appointed and the person was paid from MGNREGS fund at the rate of Rs.233 per day which was the minimum wage rate of Punjab Government.

\section{Conclusion:}

Before conclusion, I wish to mention that creation of assets was given importance in the panchayat than employment generation so more materials were used and thus costs were high. In fact as mentioned already by referring official source in Punjab, market wage rate is much higher than minimum wage rate so availability of labour at the Government rate under MGNREGS is a great issue. So the creation of assets in convergence mood is praiseworthy.

\section{References:}

[1] http://nrega.nic.in/Circular_Archive/archive/guidelines_for_New_works.pdf/9 September 2017

[2] http://ruraldiksha.nic.in/RuralDashboard/MGNREGA_NEW.aspx/dt10 September 2017

[3] http://nrega.nic.in/netnrega/guidelines.aspx/11 September 2017.

[4] Hindustan Times, "Golden Temple ranked 3rd on country's tourist attraction list", $19^{\text {th }}$ May 2016, epaper.

[5] Nair Shalini "MGNREGA wages less than minimum farm wages in 15 states: Panel" , The Indian Express, July 10, 2017 


\section{Illustrative Figures/Images Section}
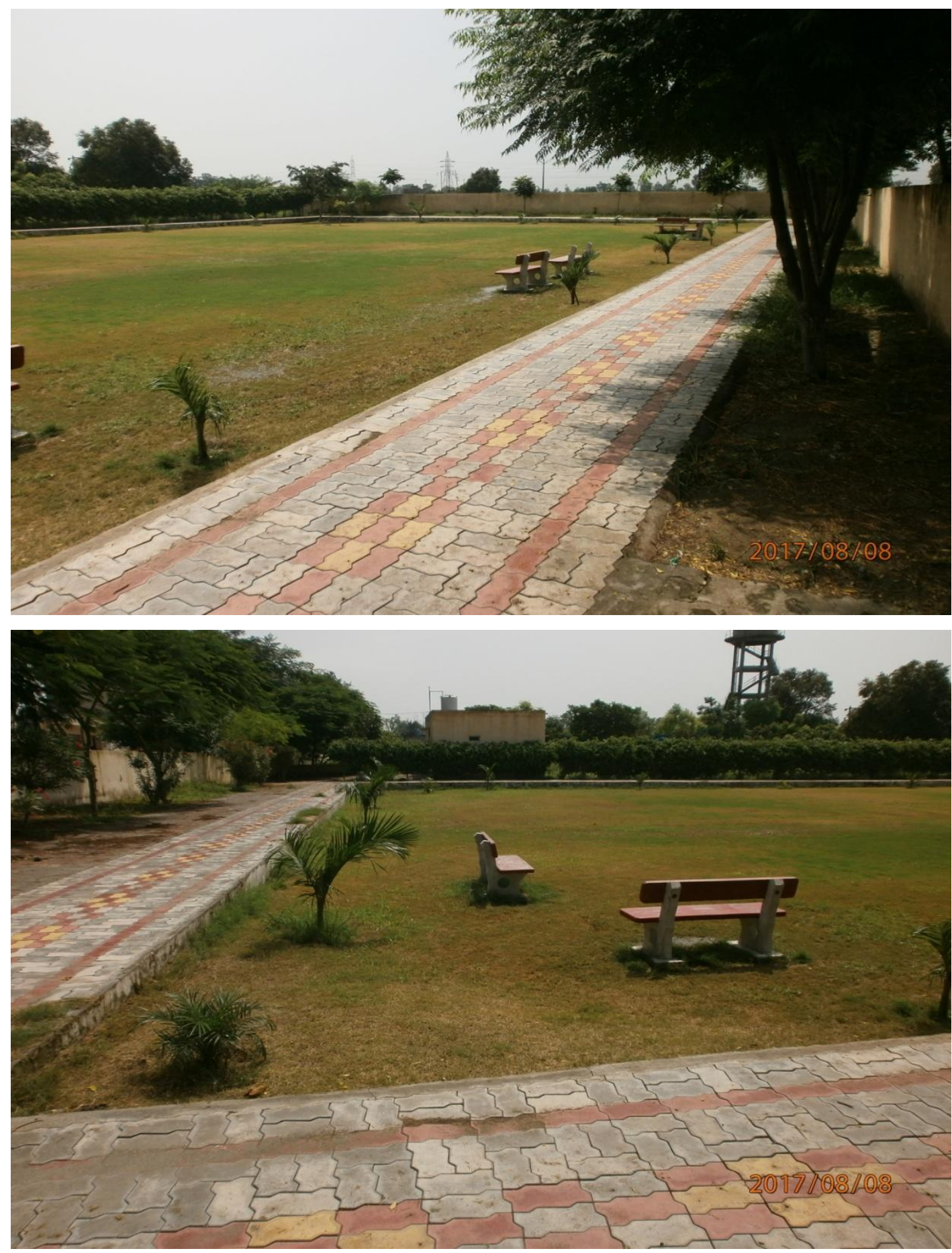

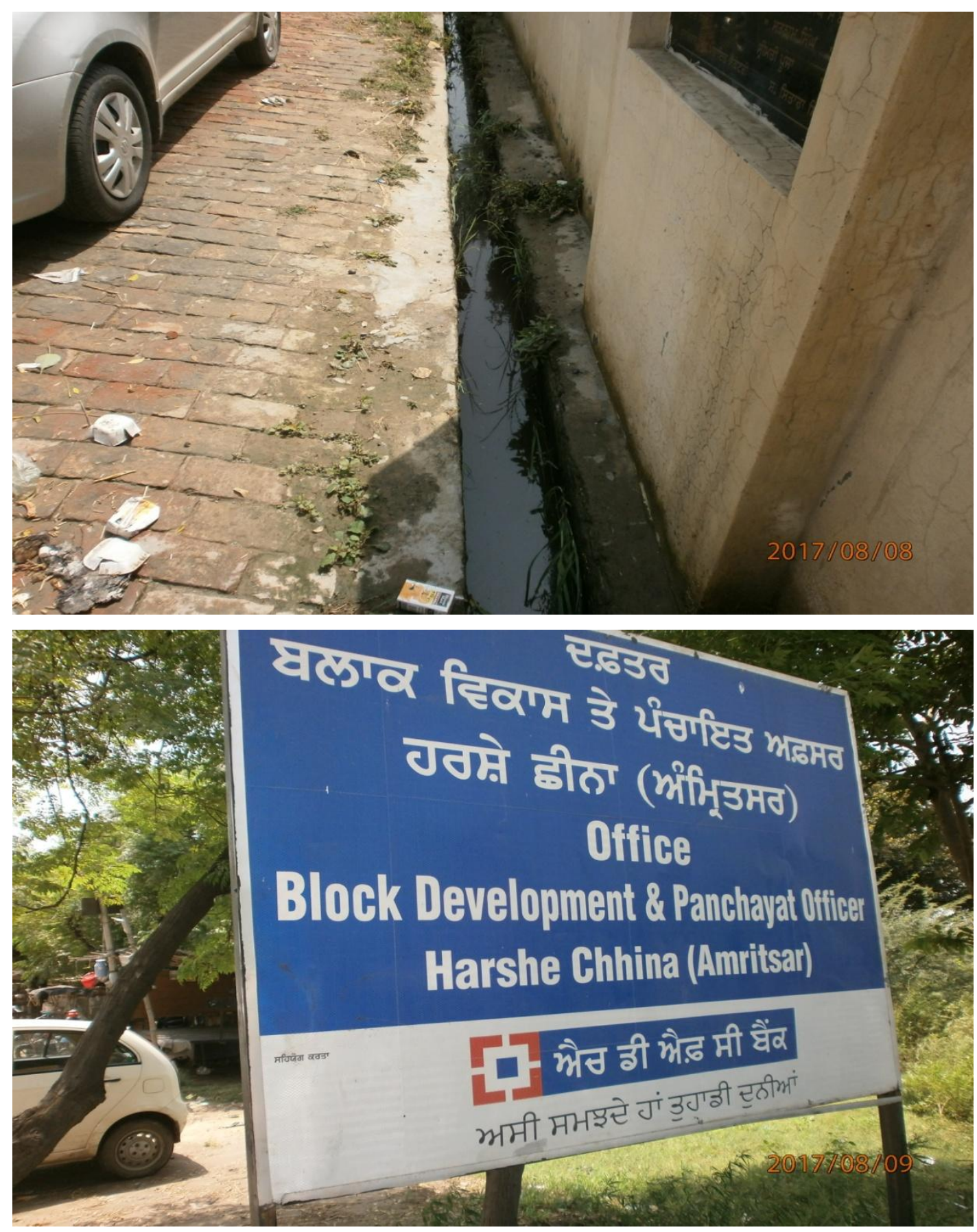